EGU2020-9768

https://doi.org/10.5194/egusphere-egu2020-9768

EGU General Assembly 2020

(c) Author(s) 2021. This work is distributed under

the Creative Commons Attribution 4.0 License.

\title{
A Comparison of Major and Trace Element Compositions of Chromites from the Stillwater, Bushveld and Great Dyke Layered Intrusions with Chromites from Komatiites, Boninites and Large Igneous Provinces.
}

Sarah-Jane Barnes, Eduardo Mansur, Philippe Pagé, Julien Meric, and Jean-Philippe Arguin Sciences de la Terre, Université du Québec à Chicoutimi, Chicoutimi, G7H2B1 Canada (sjbarnes@uqac.ca)

The composition of the magmas from which the chromites that form the massive chromite layers of the Stillwater, Great Dyke and Bushveld Complexes are of interest both to understand the economic importance of the resources in the layers ( $\mathrm{Cr}$ and PGE), but also in understanding how these layers form. Magmas that have been suggested as parental to the intrusions are boninites or crustally contaminated komatiites. Another magma that could be considered in recognition of the continental setting of the Bushveld and Great Dyke is picrite associated with continental flood basalts. In order to investigate whether any of these magmas are suitable parental magmas for the chromites we have determined major and trace elements in komatiites of low metamorphic grade, boninites and chromites from low-Ti and high-Ti picrites of the Emeishan Provence.

In order to test whether the chromites are in equilibrium with volcanic magmas we first modelled the major and minor element composition of the chromites that should have crystallized from the komatiite, boninites and picrite liquids using SpinMelt v2. The compositions are approximately correct. In terms of major and minor elements none of the chromites from the layered intrusions match boninite chromites. The Great Dyke chromites are similar to chromites from komatiites. The chromites the Bushveld are slightly more evolved with higher Ti contents and lower $\mathrm{Cr} \#$ and resemble the chromites from the low-Ti picrites of Emeishan. The Stillwater chromites have similar Ti contents to the Emeishan low-Ti picrites, but have lower $\mathrm{Cr}$. Their compositions resemble chromite compositions reported from the North Atlantic Igneous Provence.

Hafnium, Ta, Cu, Sn, Sc, Ti, Mn, Ni, Co, Mn, Ga, V and $\mathrm{Zn}$ were determined by LA-ICP-MS. To compare the composition of the chromites an estimate of their partition coefficients into chromite was made based on the concentrations of elements in komatiite chromite divided by element in komatiite. The elements were then arranged in order of compatibility and the chromites normalized to the median komatiite chromite. Podiform chromites from boninites are depleted in most elements and none of the layered intrusions chromites resemble them. The chromites from the Great Dyke have essentially flat patterns close to 1 times komatiite, but with negative $\mathrm{Cu}$ anomaly and a slight positive Sn anomaly. The Bushveld and Stillwater chromites are richer in Al, $\mathrm{Ga}, \mathrm{V}$ and $\mathrm{Ti}$ than the komatiite chromite and are depleted in $\mathrm{Cu}$. The patterns resemble the 
chromites form the low Ti-picrites form $\mathrm{Sn}$ to $\mathrm{Zn}$, but differ from picrites from $\mathrm{Hf}$ to $\mathrm{Cu}$. The picrites are enriched in $\mathrm{Hf}, \mathrm{Ta}$ and $\mathrm{Cu}$.

The chromite compositions suggest that boninite magmas are not involved in forming the chromites from layered intrusions. The Great Dyke chromites appear to have a komatiitic affinity. The Bushveld and Stillwater chromites appear to have a low-Ti picrite affinity. 